\title{
Fasting blood glucose is a novel prognostic indicator for extranodal natural killer/T-cell lymphoma, nasal type
}

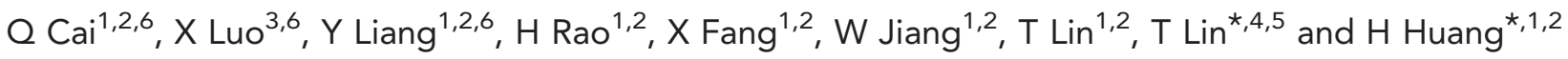

${ }^{1}$ Department of Medical Oncology, Cancer Center, Sun Yat-sen University, 651 Dong Feng RD East, Guangzhou 510060, PR China; ${ }^{2}$ State Key Laboratory of Oncology in Southern China, Guangzhou 510060, PR China; ${ }^{3}$ Department of Clinical Medicine, Zhongshan School of Medicine, Sun Yat-sen University, 74 Zhongshan Road II, Guangzhou 510080, PR China; ${ }^{4}$ Department of Urology, Sun Yat-sen Memorial Hospital, Sun Yat-sen University, Guangzhou 510120, PR China and ${ }^{5}$ Lin Bai-xin Medical Research Center, Sun Yat-sen Memorial Hospital, Sun Yat-sen University, 107 Yan Jiang RD West, Guangzhou 510120, PR China

Background: Extranodal natural killer (NK)/T-cell lymphoma, nasal type (ENKTL) is an aggressive disease with poor prognosis, requiring risk stratification. However, the prognosis of ENKTL is not fully defined and needs supplementation. We hypothesised that fasting blood glucose (FBG) may be a new prognostic factor for ENKTL.

Methods: We retrospectively analysed 130 patients newly diagnosed with ENKTL.

Results: Both univariate analysis and multivariate analysis revealed that FBG $>100 \mathrm{mg} \mathrm{dl}^{-1}$ was associated with a poor outcome. Patients with FBG $>100 \mathrm{mg} \mathrm{dl}^{-1}$ at diagnosis had more adverse clinical features, achieved lower complete remission rates $(P=0.003)$ and had worse overall survival $(P<0.001)$ and progression-free survival $(P<0.001)$ compared with low-FBG patients. Measurement of FBG was helpful in differentiating between low-risk patients using the International Prognostic Index (IPI) and Prognosis Index for peripheral T-cell lymphoma (PIT) scoring and patients in a different category using the Korean Prognostic Index (KPI) scores with different survival outcomes $(P<0.05)$.

Conclusion: Our data suggest that measuring FBG levels at diagnosis is a novel, independent predictor of prognosis in ENKTL and helps to distinguish low-risk patients with poor survival, and this holds true in patients considered low-risk by IPI, PIT and $\mathrm{KPI}$.

Extranodal natural killer (NK)/T-cell lymphoma, nasal type (ENKTL), is a distinct entity of non-Hodgkin's lymphoma in the World Health Organisation (WHO) classification system (Ai et al, 2012), which is quite rare in Western populations, but relatively common in East Asia (especially China) and Latin America (Harris et al, 1999; Vose et al, 2008). ENKTL accounts for $7-10 \%$ of all non-Hodgkin lymphomas in Asia and Latin America (Gill et al, 2010). ENKTL is an aggressive disease with poor prognosis, as optimal treatment strategies have not been fully defined
(Al-Hakeem et al, 2007). Therefore, analysis of prognostic factors at the time of diagnosis is important for optimisation of treatment strategies for individual patients. Several potential prognostic factors for survival in patients with ENKTL have been investigated, including regional lymph node involvement (You et al, 2004), elevated lactate dehydrogenase (LDH) (Lee et al, 2005), poor performance (Lee et al, 2005), paranasal extension (Logsdon et al, 1997; Li et al, 1998), presence of B symptoms (Kim et al, 2001), high Epstein-Barr virus (EBV) DNA titres (Au et al, 2004) and

*Correspondence: Dr H Huang; E-mail: huang_sysu@163.com

or Dr T Lin; E-mail: tianxinl@sina.com

${ }^{6}$ These authors contributed equally to this work

Received 22 August 2012; revised 29 October 2012; accepted 21 November 2012; published online 8 January 2013

(c) 2013 Cancer Research UK. All rights reserved 0007-0920/13 
absolute lymphocyte counts (Huang et al, 2011). The International Prognostic Index (IPI) has prognostic value in many subtypes of non-Hodgkin's lymphoma, but its value in ENKTL remains controversial (Chim et al, 2004). Although most studies demonstrated that the low-risk IPI category was associated with better survival outcome in ENKTL, the distribution of patients in different risk groups was unbalanced (Lee et al, 2006). Gallamini et al (2004) proposed PIT, the Prognosis Index for peripheral T-cell lymphoma, unspecified (PTCL-U) to identify different outcomes of PTCL-U. Recently, PIT has also been used in other subtypes of T-cell lymphoma and been proven effective (Rodriguez et al, 2007). However, the value of PIT to predict the prognosis of ENKTL remains unclear. Given the limitations of the IPI and PIT scoring systems, the Korean Prognostic Index (KPI) and local tumour invasiveness in ENKTL were proposed, and demonstrated better predictive discrimination than the IPI or PIT scoring system (Lee et al, 2006). In addition, this model might be further improved by other laboratory data (such as haemoglobin and platelet counts) and pathologic characteristics (Huang et al, 2011).

Recent clinical research has suggested that blood glucose levels in cancer patients may be an important prognostic indicator (Richardson and Pollack, 2005; LeRoith et al, 2008). Elevated blood glucose levels have been shown to predict shorter survival times in stomach cancer (Zhou et al, 2010), lung cancer (Luo et al, 2012), pancreatic cancer (Li et al, 2011), breast cancer (Erickson et al, 2011), colorectal cancer (Meyerhardt et al, 2003), endometrial cancer (Friberg et al, 2007), cervical cancer (Lee et al, 2010) and acute lymphocytic leukaemia (Sonabend et al, 2009). To the best of our knowledge, the prognostic value of fasting blood glucose (FBG) has never been studied in patients with ENKTL. In our pilot study, we observed that patients with higher FBG levels had worse outcomes in clinical practice. The objective of this retrospective analysis was to assess whether FBG at diagnosis has prognostic significance in patients with ENKTL, nasal type.

\section{MATERIALS AND METHODS}

Patients. We retrospectively reviewed the medical records of 130 newly diagnosed patients with ENKTL between January 2003 and April 2010 at Sun Yat-sen University Cancer Centre, China. The criteria for case inclusion were as follows: (i) pathologically confirmed diagnosis of NK/T-cell lymphoma, based on the WHO Classification of Tumours of Hematopoietic and Lymphoid Tissues; (ii) NK/T-cell type demonstrated by immunohistochemistry, flow cytometry or EBV in situ hybridisation; (iii) no previous malignancy or a second primary tumour; (iv) no previous treatment and (v) adequate clinical information and follow-up data. Patients were excluded if: (1) they were negative for EBV by in situ hybridisation; (2) they had blasting NK-cell lymphoma/ leukaemia; (3) aggressive NK-cell leukaemia; (4) PTCL-U and (5) patients had taken medications that increased FBG before diagnosis. We obtained approval from the Institutional Review Board of Sun Yat-Sen University Cancer Centre. Informed consent for the collection of medical information was provided at the first visit of all patients. All pathologic specimens were reviewed and reclassified by central review according to the WHO criteria for pathologic diagnosis. Antibodies to the following antigens were used for immunophenotype analysis: CD3, CD56, TIA-1, Gram-B, CD45RO, CD20, CD79a, CD30, Ki67 and the anaplastic large cell lymphoma kinase. In situ hybridisation was used for the detection of EBV-encoded RNA.

Data collection. The data were collected at diagnosis, including patient demographics, diabetes mellitus (DM) status, height, weight, \% body mass index (BMI), FBG, Eastern Cooperative Oncology Group performance status (ECOG PS), primary site, involved sites, systemic B symptoms, complete blood count, serum $\mathrm{LDH}$, biochemical profile, findings of bone marrow examinations and computed tomography scans of the thorax, abdomen and pelvic cavity. ENKTL was classified into two subsets based on the anatomic distribution of the tumour at presentation (Logsdon et al, 1997; Rodriguez et al, 2007). Upper aerodigestive tract NK/T-cell lymphoma (UNKTL) was defined as a primary tumour involving the nasal cavity, nasopharynx and upper aerodigestive tract. Extraupper aerodigestive tract NK/T-cell lymphoma (EUNKTL) was defined as primary tumours at all sites other than UNKTL sites. All patients were staged using the Ann Arbour staging system (Lamkin et al, 2009). Fasting blood glucose was measured when patients had not eaten for at least $8 \mathrm{~h}$, by clinical laboratories using standard quality assurance. According to American Diabetes Association (ADA) criteria, patients were classified into two groups according to the degree of FBG (Luo et al, 2012): (1) euglycemic group, those who had FBG concentrations $\leqslant 100 \mathrm{mg} \mathrm{dl}^{-1}$ and (2) hyperglycemic group, whose FBG concentrations $>100 \mathrm{mg} \mathrm{dl}^{-1}$.

Response criteria. The treatment response was evaluated according to the International Working Group Recommendations for Response Criteria for non-Hodgkin's lymphoma (Cheson et al, 1999; Grillo-Lopez et al, 2000).

Statistical analyses. Overall survival (OS) was measured from the date of diagnosis to the date of death from any cause or to the date of the last follow-up visit. Progression-free survival (PFS) was calculated from diagnosis to first progression, relapse after response or death from any cause, or to the date of last followup. Categorical characteristics were compared by $\chi^{2}$ test or Fisher's exact test. Overall survival and PFS were estimated using the Kaplan-Meier method. The significance of differences between survival curves was tested using the log-rank test. Significant variables in the univariate analysis were considered as variables for the multivariate analysis of survival. The latter was performed by the Cox regression mode. $P<0.05$ was considered statistically significant, and all $P$-values corresponded to two-sided significance tests. Statistical analysis was performed using SPSS 18.0 software (SPSS Inc., Chicago, IL, USA).

\section{RESULTS}

Patient characteristics. The clinical characteristics of the 130 patients are shown in Table 1. Men predominated, and the median age was 43 years (range, 11-74). Seventy patients had B symptoms $(53.8 \%)$ at presentation, and most patients had localised diseases (Ann Arbour stages I, II; $n=100 ; 76.9 \%$ ). In patients with EUNKTL, the primary lesion sites were skin or soft tissue $(n=6)$, gastrointestinal tract $(n=4)$, adrenal gland $(n=2)$ and others $(n=2)$. The median FBG at diagnosis was $92.9 \mathrm{mg} \mathrm{dl}^{-1}$ (range: 61.0-193.7). Only two patients with $\mathrm{FBG}>100 \mathrm{mgdl}^{-1}$ at diagnosis had been diagnosed with $\mathrm{DM}$ for $>10$ years and took insulin daily to control blood glucose. Baseline clinical features of patients with $\mathrm{FBG} \leqslant 100 \mathrm{mg} \mathrm{dl}^{-1}$ at diagnosis were compared with those of patients with FBG $>100 \mathrm{mgdl}^{-1}$ at diagnosis. No significant between-group difference was observed for age, gender and different groups of IPI, KPI and PIT. In addition, the ratio of hyperglycaemia was not statistically different among BMI, B symptom, Ann Arbour stage, regional lymph node involvement, subtypes and LDH levels (Table 1). Patients with FBG $>100 \mathrm{mg} \mathrm{dl}^{-1}$ at diagnosis tended to have worse ECOG PS, a higher chance of having albumin levels $<35 \mathrm{gl}^{-1}$ and thrombocytopenia.

Treatment modalities and response. The primary treatment modalities were as follows: (i) no treatment (8 cases); (ii) chemotherapy alone (80 cases) and (iii) chemotherapy followed 
Table 1. Baseline clinical characteristics according to fasting blood glucose (FBG) levels at diagnosis (FBG $\leqslant 100 \mathrm{mg} \mathrm{dl}^{-1}$ vs FBG $>100 \mathrm{mg} \mathrm{dl}^{-1}$ )

\begin{tabular}{|c|c|c|c|}
\hline Characteristics & $\begin{array}{l}\text { Glucose level } \\
\leqslant 100 \mathrm{mg} \mathrm{dl}^{-1} \\
n(\%)\end{array}$ & $\begin{array}{l}\text { Glucose level } \\
>100 \mathrm{mg} \mathrm{dl}^{-1} \\
n(\%)\end{array}$ & $P$-value \\
\hline No. of patients & $94(72.3)$ & $36(27.7)$ & \\
\hline $\begin{array}{l}\text { Diagnosis of } \\
\text { diabetes }\end{array}$ & & & 0.075 \\
\hline Yes & $0(0)$ & $2(5.6)$ & \\
\hline No & $94(100.0)$ & $34(94.4)$ & \\
\hline $\begin{array}{l}\text { Age (median } \\
\text { (range), years) }\end{array}$ & $43(11-74)$ & $44(31-70)$ & 0.802 \\
\hline$\leqslant 60$ & $80(85.1)$ & $30(83.3)$ & \\
\hline$>60$ & $14(14.9)$ & $6(16.7)$ & \\
\hline Gender & & & 0.403 \\
\hline Female & $22(23.4)$ & $6(16.7)$ & \\
\hline Male & $72(76.6)$ & $30(83.3)$ & \\
\hline ECOG PS & & & 0.022 \\
\hline $0-1$ & $88(93.6)$ & $28(77.8)$ & \\
\hline$\geqslant 2$ & $6(6.4)$ & $8(22.2)$ & \\
\hline BMI $\left(\mathrm{kg} \mathrm{m}^{-2}\right)^{a}$ & & & 0.595 \\
\hline$<18.5$ & $26(29.5)$ & $6(20.0)$ & \\
\hline $18.5-<25$ & $46(52.3)$ & $18(60.0)$ & \\
\hline$\geqslant 25$ & $16(18.2)$ & $6(20.0)$ & \\
\hline Mass & & & 1 \\
\hline$<5 \mathrm{~cm}$ & $82(87.2)$ & 32 (88.9) & \\
\hline$\geqslant 5 \mathrm{~cm}$ & $12(12.8)$ & $4(11.1)$ & \\
\hline B symptom & & & 0.586 \\
\hline+ & $52(55.3)$ & $18(50.0)$ & \\
\hline- & $42(44.7)$ & $18(50.0)$ & \\
\hline Ann Arbour stage & & & 0.283 \\
\hline$|-| \mid$ & $70(74.5)$ & $30(83.3)$ & \\
\hline III-IV & $24(25.5)$ & $6(16.7)$ & \\
\hline Regional lymph & & & 0.499 \\
\hline node involvement & & & \\
\hline+ & 48 (51.1) & $16(44.4)$ & \\
\hline- & $46(48.9)$ & $20(55.6)$ & \\
\hline Extranodal sites & & & 0.695 \\
\hline$<2$ & $66(70.2)$ & $24(66.7)$ & \\
\hline$\geqslant 2$ & $28(29.8)$ & $12(33.3)$ & \\
\hline Bone marrow & & & 0.669 \\
\hline Involvement & $4(4.3)$ & $2(5.6)$ & \\
\hline+ & $90(95.7)$ & $34(94.4)$ & \\
\hline- & & & \\
\hline Subtypes & & & 1 \\
\hline UNKTL & $84(89.4)$ & $32(88.9)$ & \\
\hline EUNKTL & $10(10.6)$ & $4(11.1)$ & \\
\hline IPI score ${ }^{b}$ & & & 0.278 \\
\hline $0-1$ & $70(76.1)$ & $24(66.7)$ & \\
\hline $2-5$ & 22 (33.9) & $12(33.3)$ & \\
\hline PIT score ${ }^{b}$ & & & 0.097 \\
\hline $0-1$ & $82(89.1)$ & $28(77.8)$ & \\
\hline $2-4$ & $10(10.9)$ & $8(22.2)$ & \\
\hline KPI score ${ }^{b}$ & & & 0.313 \\
\hline $0-1$ & $50(54.3)$ & $16(44.4)$ & \\
\hline $2-4$ & $42(45.7)$ & $20(55.6)$ & \\
\hline WBC & & & 0.181 \\
\hline$<4.0 \times 10^{9} \mathrm{I}^{-1}$ & $12(12.8)$ & $8(22.2)$ & \\
\hline$\geqslant 4.0 \times 10^{9} I^{-1}$ & $82(87.2)$ & $28(77.8)$ & \\
\hline ALC & & & 0.886 \\
\hline$<1.0 \times 10^{9} \mathrm{I}^{-1}$ & $22(23.4)$ & $8(22.2)$ & \\
\hline$\geqslant 1.0 \times 10^{9} \mathrm{I}^{-1}$ & $72(76.6)$ & $28(77.8)$ & \\
\hline Haemoglobin & & & 0.604 \\
\hline$<110 \mathrm{gl}^{-1}$ & $22(23.4)$ & $10(27.8)$ & \\
\hline$\geqslant 110 \mathrm{gl}^{-1}$ & $72(76.6)$ & $26(72.2)$ & \\
\hline
\end{tabular}

Table 1. (Continued)

\begin{tabular}{|c|c|c|c|}
\hline $\begin{array}{l}\text { Platelet counts } \\
\quad<150 \times 10^{9} \mathrm{I}^{-1} \\
\geqslant 150 \times 10^{9} \mathrm{I}^{-1}\end{array}$ & $\begin{array}{c}6(6.4) \\
88(93.6)\end{array}$ & $\begin{array}{l}10(27.8) \\
26(72.2)\end{array}$ & 0.002 \\
\hline $\begin{array}{l}\text { Total protein } \\
\quad<60 \mathrm{gl}^{-1} \\
\geqslant 60 \mathrm{gl}^{-1}\end{array}$ & $\begin{array}{l}10(10.6) \\
84(89.4)\end{array}$ & $\begin{array}{r}8(22.2) \\
28(77.8)\end{array}$ & 0.153 \\
\hline $\begin{array}{l}\text { Albumin } \\
\qquad<35 \mathrm{gl}^{-1} \\
\geqslant 35 \mathrm{gl}^{-1}\end{array}$ & $\begin{array}{l}16(17.0) \\
78(83.0)\end{array}$ & $\begin{array}{l}12(33.3) \\
24(66.7)\end{array}$ & 0.043 \\
\hline $\begin{array}{l}\mathrm{LDH}^{\mathrm{b}} \\
\quad \leqslant 245 \mathrm{U} \mathrm{ml}^{-1} \\
\quad>245 \mathrm{Uml}^{-1}\end{array}$ & $\begin{array}{l}68(73.9) \\
24(26.1)\end{array}$ & $\begin{array}{l}22(61.1) \\
14(38.9)\end{array}$ & 0.154 \\
\hline \multicolumn{4}{|c|}{$\begin{array}{l}\text { Abbreviations: EUNKTL = extraupper aerodigestive tract NK/T-cell lymphoma; ECOG PS = } \\
\text { Eastern Cooperative Oncology Group performance status; BMI=body mass index; IPI = } \\
\text { International Prognostic Index; PIT = Prognostic Index for Peripheral T-cell lymphoma } \\
\text { unspecified; } \mathrm{KPI}=\mathrm{Korean} \text { Prognostic Index; WBC = white blood cell; ALC=absolute } \\
\text { lymphocyte count; LDH = lactate dehydrogenase. } \\
{ }^{\mathrm{a} C} \text { Complete information on BMI was available in } 118 \text { cases. } \\
{ }^{b} \text { Complete information on IPI score, PIT score, } \mathrm{KPI} \text { score or LDH was available in } 128 \text { cases }\end{array}$} \\
\hline
\end{tabular}

Table 2. Treatment of patients according to fasting blood glucose (FBG) levels at diagnosis (FBG $\leqslant 100 \mathrm{mg} \mathrm{dl}^{-1}$ vs FBG $>100 \mathrm{mg} \mathrm{dl}^{-1}$ )

\begin{tabular}{|c|c|c|c|}
\hline Treatment & $\begin{array}{l}\mathrm{FBG} \leqslant 100 \mathrm{mg} \mathrm{dl}^{-1} \\
\text { (no. of patients) }\end{array}$ & $\begin{array}{l}\text { FBG }>100 \mathrm{mg} \mathrm{dl}^{-1} \\
\text { (no. of patients) }\end{array}$ & $\begin{array}{c}\boldsymbol{P} \text { - } \\
\text { value }\end{array}$ \\
\hline Patient treated & 94 & 36 & 0.616 \\
\hline No treatment & 6 & 2 & \\
\hline $\begin{array}{l}\text { Chemotherapy } \\
\text { alone }\end{array}$ & 60 & 20 & \\
\hline $\begin{array}{l}\text { Chemotherapy } \\
\text { followed by } \\
\text { radiotherapy }\end{array}$ & 28 & 14 & \\
\hline $\begin{array}{l}\text { Anthracyclines } \\
\text { used }\end{array}$ & 70 & 28 & \begin{tabular}{|l|}
0.727 \\
\end{tabular} \\
\hline $\begin{array}{l}\text { L-asparaginase } \\
\text { used }\end{array}$ & 16 & 4 & 0.391 \\
\hline Efficacy & & & 0.003 \\
\hline CR unachieved & 36 & 24 & \\
\hline CR achieved & 52 & 10 & \\
\hline
\end{tabular}

by radiotherapy ( 42 cases). The regimens of chemotherapy in the initial treatment included: CHOP (cyclophosphamide, doxorubicin, vincristine and prednisone $)$, CHOP-like [(CHOP + L-asparaginase), $\mathrm{CHOP}+\mathrm{HD}-\mathrm{MTX}$ (CHOP + high-dose methotrexate), CHOPE (CHOP + etoposide)], EPOCH (etoposide, doxorubicin, vincristine, cyclophosphamide, prednisone), alternating triple therapy regimen (CHOP-B, IMVP-16 and DHAP), CHOP-B (cyclophosphamide, doxorubicin, vincristine, prednisone and bleomycin), IMVP-16 (ifosfamide, etoposide, methotrexate), DHAP (dexamethasone, cytarabine, cisplatin)], GEMOX (gemcitabine, oxaliplatin), GEMOX + L-asparaginase, SMILE (dexamethasone, methotrexate, ifosfamide, L-asparaginase, etoposide) and vincristine $+\mathrm{L}$-asparaginase + dexamethasone. The treatment details and outcomes are listed in Table 2. No significant difference was observed in the treatment modalities between patients grouped by $\mathrm{FBG} \leqslant 100 \mathrm{mg} \mathrm{dl}^{-1}$ and $\mathrm{FBG}>100 \mathrm{mg} \mathrm{dl}^{-1}$ at diagnosis. In the initial treatment modality, 122 patients $(93.8 \%)$ were evaluated for treatment responses, and 62 patients (50.8\%) achieved complete remission (CR). The rate of $\mathrm{CR}$ in the initial treatment was significantly lower in patients with $\mathrm{FBG}>100 \mathrm{mg} \mathrm{dl}^{-1}$ $(P=0.003)$. 
Survival and prognostic factors. The median survival time was 31.7 months (95\% confidence interval (CI): 21.4-42.0), and the estimated 5-year OS and PFS rate in 130 patients was $51.2 \%$ and $30.8 \%$, respectively (Figure 1 ). At the time of analysis, 78 patients $(60.0 \%)$ had died because of tumour progression $(n=72)$, treatment-related toxicity $(n=2)$ and unknown causes $(n=4)$. The 5-year estimate for OS was $61.9 \%$ for patients with FBG $\leqslant 100 \mathrm{mg} \mathrm{dl}^{-1}$ and $26.3 \%$ for those with $\mathrm{FBG}>100 \mathrm{mg} \mathrm{dl}^{-1}$ $\left(P<0.001\right.$; Figure 2A). Patients with FBG $>100 \mathrm{mg} \mathrm{dl}^{-1}$ at diagnosis also had worse 5-year PFS than patients with low FBG at diagnosis ( $9.8 \%$ vs $38.8 \%, P<0.001$; Figure $2 \mathrm{~B}$ ). Table 3 shows the results of univariate and multivariate analyses of clinical variables considered as predictors of OS and PFS.

The distribution of patients within risk groups based on IPI, PIT and KPI scores is presented in Table 4. Using the IPI and PIT scoring systems, $>70 \%$ of all cases were in the low-risk category (with no or one adverse factor), but these two prognostic models failed to differentiate between patients with different outcomes in the low-risk group. The KPI model balanced distribution of patients into different risk groups better than the IPI and PIT models. For patients in the low-risk category
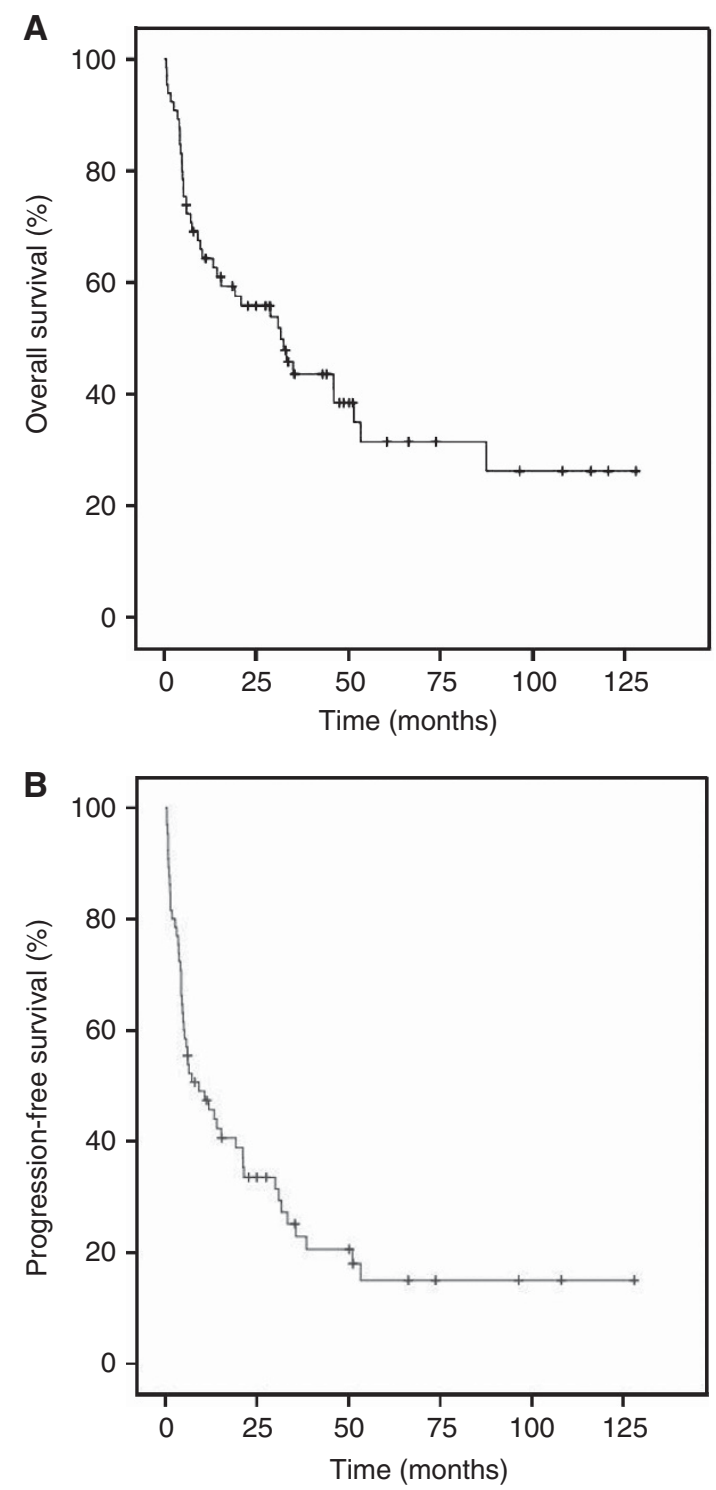

Figure 1. (A) Overall survival of 130 patients with extranodal natural killer T-cell lymphoma, nasal type (ENKTL). (B) Progression-free survival of 130 patients with ENKTL, nasal type. according to IPI and PIT, FBG at diagnosis could distinguish between those with good outcomes and those with poor outcomes. Patients with FBG $\leqslant 100 \mathrm{mg} \mathrm{dl}^{-1}$ at diagnosis had better survival than those with $\mathrm{FBG}>100 \mathrm{mg} \mathrm{dl}^{-1}$ (5-year OS of low-risk IPI: $54.3 \%$ vs $25.0 \%, P=0.013$; 5-year OS of low-risk PIT: $51.2 \%$ vs $21.4 \%, P=0.006)$. In the KPI prognostic model, FBG also helped to differentiate between patients with different prognosis in the category of no or one risk factor (5-year OS: $72.0 \%$ vs 37.5\%, $P=0.013$ ) and two or more than two risk factors (5-year OS: $19.0 \%$ vs $0 \%, P=0.046)$.

\section{DISCUSSION}

Our study identified that FBG $>100 \mathrm{mg} \mathrm{dl}^{-1}$ was independently associated with poor survival in patients with ENKTL.

The value of hyperglycaemia for prognosis in a range of malignancies was previously investigated (Zhou et al, 2010) and demonstrated an inverse relationship between glucose levels and length of survival time in stomach cancer (Zhou et al, 2010), lung
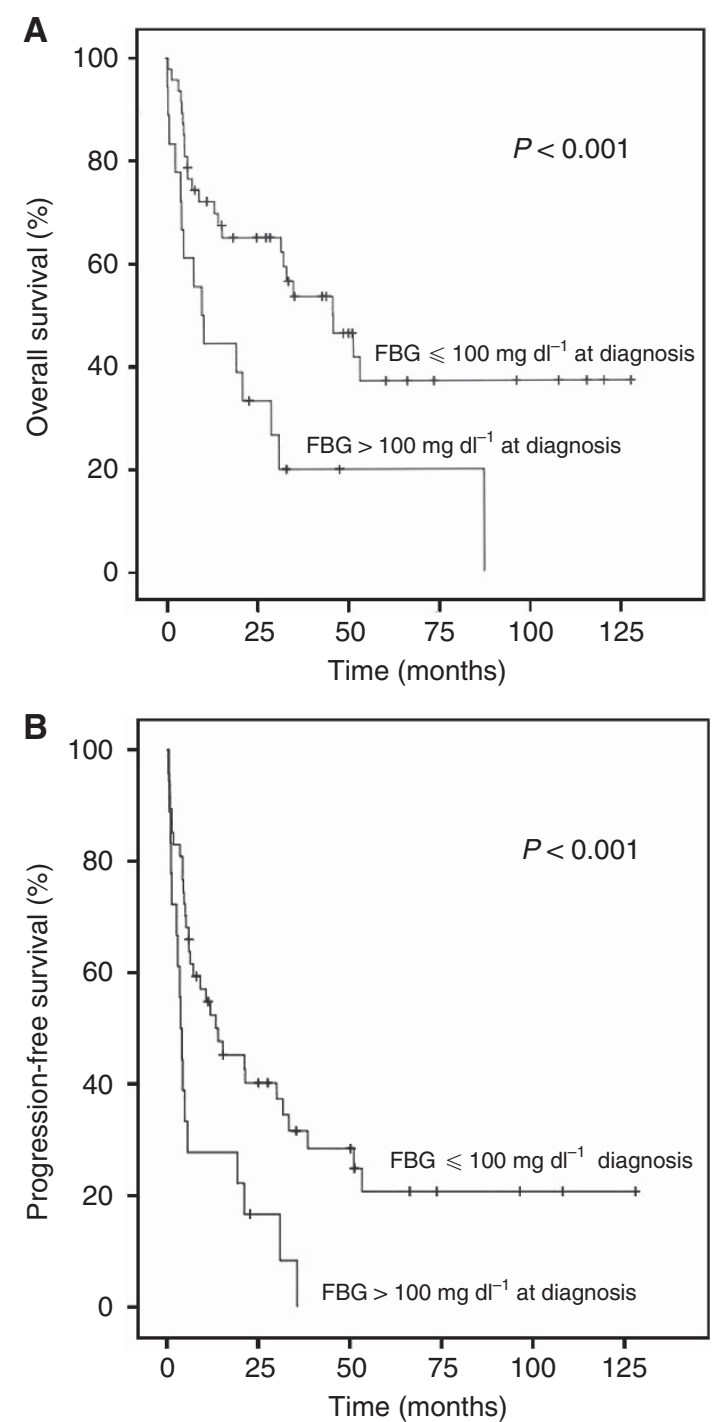

Figure 2. (A) Overall survival of patients according to fasting blood glucose (FBG) $\leqslant 100 \mathrm{mg} \mathrm{dl}^{-1}$ vs $>100 \mathrm{mg} \mathrm{dl}^{-1}$ at diagnosis. (B) Progression-free survival of patients according to $\mathrm{FBG} \leqslant 100 \mathrm{mg} \mathrm{dl}^{-1}$ vs $>100 \mathrm{mg} \mathrm{dl}^{-1}$ at diagnosis. 


\begin{tabular}{|c|c|c|c|c|c|c|}
\hline \multirow[b]{3}{*}{ Parameters } & \multicolumn{3}{|c|}{ OS } & \multicolumn{3}{|c|}{ PFS } \\
\hline & \multirow{2}{*}{\begin{tabular}{|c} 
Univariate analysis \\
$\boldsymbol{P}$-value
\end{tabular}} & \multicolumn{2}{|c|}{ Multivariate analysis } & \multirow{2}{*}{\begin{tabular}{|c} 
Univariate analysis \\
$P$-value
\end{tabular}} & \multicolumn{2}{|c|}{ Multivariate analysis } \\
\hline & & $\mathrm{RR}(95 \% \mathrm{Cl})$ & $P$-value & & $\mathrm{RR}(95 \% \mathrm{Cl})$ & $P$-value \\
\hline Age $>60$ years & 0.345 & & & 0.408 & & \\
\hline Gender, male & 0.889 & & & 0.764 & & \\
\hline BMI & 0.101 & & & 0.095 & & \\
\hline ECOG PS $(\geqslant 2)$ & $<0.001$ & & & 0.004 & & \\
\hline B symptoms & 0.065 & & & 0.016 & & \\
\hline Ann Arbour (III-IV) & 0.007 & & & 0.002 & & \\
\hline $\operatorname{WBC}\left(<4.0 \times\left. 10^{9}\right|^{-1}\right)$ & $<0.001$ & & & 0.007 & & \\
\hline $\operatorname{ALC}\left(<1.0 \times 10^{9} I^{-1}\right)$ & $<0.001$ & & & 0.002 & $2.259(1.374-3.714)$ & 0.001 \\
\hline Haemoglobin $\left(<110 \mathrm{gl}^{-1}\right)$ & 0.002 & & & 0.06 & & \\
\hline Platelet counts $\left(<150 \times\left. 10^{9}\right|^{-1}\right)$ & $<0.001$ & & & 0.002 & & \\
\hline Total protein $\left(<60 \mathrm{gl}^{-1}\right)$ & $<0.001$ & $5.648(3.020-10.562)$ & $<0.001$ & $<0.001$ & & \\
\hline Albumin $\left(<35 \mathrm{gl}^{-1}\right)$ & $<0.001$ & & & 0.012 & & \\
\hline Fasting blood glucose level $\left(>100 \mathrm{mg} \mathrm{dl}^{-1}\right.$ ) & $<0.001$ & $2.824(1.745-4.569)$ & $<0.001$ & $<0.001$ & $2.094(1.321-3.320)$ & 0.002 \\
\hline $\mathrm{LDH}\left(>245 \mathrm{Uml}^{-1}\right)$ & $<0.001$ & & & & & \\
\hline Regional lymph node involvement & $<0.001$ & & & 0.003 & & \\
\hline Subtype & 0.201 & & & 0.165 & & \\
\hline Bone involvement & $<0.001$ & & & 0.008 & & \\
\hline Extranodal sites $(\geqslant 2)$ & $<0.001$ & & & $<0.001$ & $2.562(1.594-4.116)$ & $<0.001$ \\
\hline Mass $(\geqslant 5 \mathrm{~cm})$ & 0.244 & & & 0.819 & & \\
\hline IPI (2-5) & $<0.001$ & & & 0.003 & & \\
\hline KPI (2-4) & $<0.001$ & $2.638(1.578-4.411)$ & $<0.001$ & $<0.001$ & $2.053(1.306-3.228)$ & 0.002 \\
\hline PIT (2-4) & $<0.001$ & & & 0.182 & & \\
\hline $\begin{array}{l}\text { Abbreviations: } \mathrm{Cl}=\text { confidence interval; } \mathrm{ALC}=\text { absol } \\
\text { Oncology Group performance status; } \mathrm{WBC}=\text { white } \\
\mathrm{PIT}=\text { Prognostic Index for Peripheral T-cell lymphom } \\
\text { Cox regression mode was used for statistical analysi }\end{array}$ & $\begin{array}{l}\text { ymphocyte count; } O S= \\
\text { d cell; } L C=\text { lymphocyte } \\
\text { ispecified. } \\
\quad 0.05 \text { was considered st }\end{array}$ & $\begin{array}{l}\text { verall survival; } P F S=\text { pro } \\
\text { ount; } L D H=\text { lactate deh } \\
\text { stically significant. }\end{array}$ & $\begin{array}{l}\text { on-free su } \\
\text { enase; IPI }\end{array}$ & $\begin{array}{l}\text { vival; } \mathrm{BMI}=\text { body ma } \\
\text { International Prognc }\end{array}$ & $\begin{array}{l}\text { ndex; ECOG PS = Easterr } \\
\text { Index; KPI = Korean Pro }\end{array}$ & $\begin{array}{l}\text { Cooperative } \\
\text { nostic Index }\end{array}$ \\
\hline
\end{tabular}

cancer (Luo et al, 2012), ovarian carcinoma (Lamkin et al, 2009), cervical cancer (Lee et al, 2010) and acute lymphocytic leukaemia (Sonabend et al, 2009). However, the impact of FBG on the survival of patients with NHL including ENKTL has not been described. To the best of our knowledge, this clinical study is the first to observe that FBG at diagnosis is a prognostic factor of survival in ENKTL, nasal type.

In this study, we divided patients into two groups using a cutoff value of $100 \mathrm{mg} \mathrm{dl}^{-1} \mathrm{FBG}$ based on ADA criteria (Luo et al, 2012). Our data demonstrated a notable difference in clinical behaviour between the higher and lower FBG groups. Patients with $\mathrm{FBG}>100 \mathrm{mg} \mathrm{dl}^{-1}$ were more likely to develop adverse clinical features, including poor PS, lower platelet counts and lower albumin levels. In addition, patients with FBG $>100 \mathrm{mg} \mathrm{dl}^{-1}$ at diagnosis were more likely to achieve a lower rate of CR. Regardless of the association between FBG and other prognostic factors, multivariate analysis showed that FBG at diagnosis was a powerful predictor of OS and PFS in patients with ENKTL, nasal type.

Although ENKTL is a distinctive entity with poor prognosis, $>70 \%$ of the patients in our study were categorised as low-risk based on IPI and PIT scores. However, FBG at diagnosis separated patients in the low-risk category of IPI and PIT on the basis of survival outcome. When adding FBG at diagnosis to the two models, the low-risk patients were separated on the basis of different survival outcomes with sufficient statistical power.
In addition, FBG at diagnosis also separated patients in a different category of KPI score based on the survival outcome.

The biological mechanism by which hyperglycaemia increases mortality risk of patients diagnosed with ENKTL is unclear. Several potential explanations have been proposed for the observed association between hyperglycaemia and increased all-cause mortality in cancer patients (Barone et al, 2002). First, cancer patients with hyperglycaemia may have increased tumour cell proliferation and metastatic capacity as a consequence of the physiologic environment of hyperinsulinemia (Richardson and Pollack, 2005). It has been suggested that high insulin or increased free insulin-like growth factor (IGF-1) levels in hyperinsulinemic states can promote cancer cell and tumour growth (Richardson and Pollack, 2005). Second, glucose metabolism of cancer cells is different from normal cells mainly because of a lack of oxygen present in hypoxic tumour conditions. Activation of hypoxiainducible factor stimulates the expression of glycolytic enzymes and decreases reliance on mitochondrial oxidative phosphorylation in tumour cells, which occurs even under aerobic conditions. Moreover, glucose utilisation of cancer cells is significantly enhanced when compared with normal tissue because of the overexpression of five transmembrane transporters, termed GLUT1-5. GLUT is significantly associated with the likelihood of metastasis and hence poor patient prognosis (Medina and Owen, 2002; Guo et al, 2010). Third, the presence of diabetes in cancer patients may have indirect impact on cancer outcome. A study 


\begin{tabular}{|c|c|c|c|}
\hline $\begin{array}{l}\text { Prognostic } \\
\text { model }\end{array}$ & $\begin{array}{c}\text { No. of patients } \\
(\%)\end{array}$ & $\begin{array}{c}\text { 5-year OS } \\
(\%)\end{array}$ & $\boldsymbol{P}$-value \\
\hline \multicolumn{4}{|l|}{ IPI score ${ }^{a}$} \\
\hline $0-1$ & $94(73.4)$ & 46.8 & 0.003 \\
\hline $2-5$ & 34 (26.6) & 17.6 & \\
\hline \multicolumn{4}{|l|}{ PIT score ${ }^{a}$} \\
\hline $0-1$ & $110(85.9)$ & 43.6 & 0.009 \\
\hline $2-4$ & 18 (14.1) & 11.1 & \\
\hline \multicolumn{4}{|l|}{ KPI score ${ }^{a}$} \\
\hline $0-1$ & $66(51.6)$ & 63.6 & $<0.001$ \\
\hline $2-4$ & $62(48.4)$ & 12.9 & \\
\hline
\end{tabular}

Abbreviations: $\mathrm{OS}=$ overall survival; $\mathrm{IPI}=$ International Prognostic $\operatorname{Index} ; \mathrm{KPI}=$ Korean Prognostic Index; PIT = Prognostic Index for Peripheral T-cell lymphoma, unspecified. Differences between survival curves were tested using the log-rank test. $P<0.05$ was considered statistically significant.

${ }^{\mathrm{a}}$ Complete information on IPI score, PIT score and KPI score was available in 128 cases.

indicated that cancer patients with pre-existing diabetes were often treated less aggressively than those without diabetes (van de Poll-Franse et al, 2007). Thus, differences in cancer treatment between patients with and without diabetes may contribute to increased mortality. However, this proposed hypothesis was not supported by our data, which demonstrated no significant difference in cancer treatment between the two groups. In addition, patients with hyperglycaemia may have a poorer response to cancer treatment (Brunello et al, 2011). There is no direct evidence to suggest that glycaemia control can decrease cancer recurrence or cancer mortality, although data may support this hypothesis in breast cancer (Krone and Ely, 2005).

Our study has several strengths including: (1) all patients were newly diagnosed, which ruled out any impact on patients' outcomes by possible disproportionate pretreatment that patients might receive; (2) despite the limited data generally derived from retrospective hospital records review, we were able to collect and adjust for most potential prognostic factors to avoid bias; (3) we measured FBG instead of random blood glucose, and therefore this value could be used to establish a baseline to control values for all patients with the same status. However, our study was also limited in several aspects: (1) our cases included both diabetic and nondiabetic patients and therefore the impact of diabetic status was not accounted for; (2) the findings of this study may be specific to the study sample in Asian populations; (3) this was a retrospective study with a small number of patients. Therefore, a prospective study with a large number of cases is needed to confirm a correlation between FBG and ENKTL prognosis.

In conclusion, this study suggested that FBG at diagnosis is a prognostic indicator of clinical outcome in ENKTL, nasal type and may have important implications for the control of glycaemia in patients with this disease. Further investigation is required to provide a better understanding of the mechanisms underlying the association between blood glucose levels and clinical outcome. Future prospective clinical studies are required to confirm our findings.

\section{ACKNOWLEDGEMENTS}

This work was supported by National Natural Science Foundation of China (project number: 81001052, 81071688, 81272808), Science and Technology Planning Project of Guangdong Province, China (project number: 2011B031800222), Young Talents project of Sun Yat-sen University Cancer Centre (to Cai Qingqing), Young
Talents project of Sun Yat-sen University (to Cai Qingqing), Natural Science Foundation of Guangdong Province, China (project number: 8151008901000043, 07117366, 6104605), Yat-sen Scholarship for Young Scientists (to Lin Tianxin) and Program for New Century Excellent Talents in University (NCET10-0852, to Lin Tianxin).

\section{CONFLICT OF INTEREST}

The authors declare no conflict of interest.

\section{REFERENCES}

Ai WZ, Chang ET, Fish K, Fu K, Weisenburger DD, Keegan TH (2012) Racial patterns of extranodal natural killer/T-cell lymphoma, nasal type, in California: a population-based study. Br J Haematol 156(5): 626-632.

Al-Hakeem DA, Fedele S, Carlos R, Porter S (2007) Extranodal NK/T-cell lymphoma, nasal type. Oral Oncol 43(1): 4-14.

Au WY, Pang A, Choy C, Chim CS, Kwong YL (2004) Quantification of circulating Epstein-Barr virus (EBV) DNA in the diagnosis and monitoring of natural killer cell and EBV-positive lymphomas in immunocompetent patients. Blood 104(1): 243-249.

Barone BB, Yeh HC, Snyder CF, Peairs KS, Stein KB, Derr RL, Wolff AC, Brancati FL (2002) Long-term all-cause mortality in cancer patients with preexisting diabetes mellitus: a systematic review and meta-analysis. JAMA 300(23): 2754-2764.

Brunello A, Kapoor R, Extermann M (2011) Hyperglycemia during chemotherapy for hematologic and solid tumors is correlated with increased toxicity. Am J Clin Oncol 34(3): 292-296.

Cheson BD, Horning SJ, Coiffier B, Shipp MA, Fisher RI, Connors JM, Lister TA, Vose J, Grillo-Lopez A, Hagenbeek A, Cabanillas F, Klippensten D, Hiddemann W, Castellino R, Harris NL, Armitage JO, Carter W, Hoppe R, Canellos GP (1999) Report of an international workshop to standardize response criteria for non-Hodgkin's lymphomas. NCI Sponsored International Working Group. J Clin Oncol 17(4): 1244.

Chim CS, Ma SY, Au WY, Choy C, Lie AK, Liang R, Yau CC, Kwong YL (2004) Primary nasal natural killer cell lymphoma: long-term treatment outcome and relationship with the International Prognostic Index. Blood 103(1): 216-221.

Erickson K, Patterson RE, Flatt SW, Natarajan L, Parker BA, Heath DD, Laughlin GA, Saquib N, Rock CL, Pierce JP (2011) Clinically defined type 2 diabetes mellitus and prognosis in early-stage breast cancer. J Clin Oncol 29(1): 54-60.

Friberg E, Orsini N, Mantzoros CS, Wolk A (2007) Diabetes mellitus and risk of endometrial cancer: a meta-analysis. Diabetologia 50(7): 1365-1374.

Gallamini A, Stelitano C, Calvi R, Bellei M, Mattei D, Vitolo U, Morabito F, Martelli M, Brusamolino E, Iannitto E, Zaja F, Cortelazzo S, Rigacci L, Devizzi L, Todeschini G, Santini G, Brugiatelli M, Federico M (2004) Peripheral T-cell lymphoma unspecified (PTCL-U): a new prognostic model from a retrospective multicentric clinical study. Blood 103(7): 2474-2479.

Grillo-Lopez AJ, Cheson BD, Horning SJ, Peterson BA, Carter WD, Varns CL, Klippenstein DL, Shen CD (2000) Response criteria for NHL: importance of 'normal' lymph node size and correlations with response rates. Ann Oncol 11(4): 399-408.

Guo HQ, Pu XX, Guo CC, Rao HL, Li HR, Lin TY (2010) The role of Skp2 in extranodal NK/T-cell lymphoma. Chin J Cancer 29(5): 567-571.

Gill H, Liang RH, Tse E (2010) Extranodal Natural-Killer/T-cell Lymphoma, Nasal type. Adv Hematol 2010: 627401.

Harris NL, Jaffe ES, Diebold J, Flandrin G, Muller-Hermelink HK, Vardiman J, Lister TA, Bloomfield CD (1999) World Health Organization classification of neoplastic diseases of the hematopoietic and lymphoid tissues: report of the Clinical Advisory Committee meeting-Airlie House, Virginia. November 1997. J Clin Oncol 17(12): 3835-3849.

Huang JJ, Jiang WQ, Lin TY, Huang Y, Xu RH, Huang HQ, Li ZM (2011) Absolute lymphocyte count is a novel prognostic indicator in extranodal natural killer/T-cell lymphoma, nasal type. Ann Oncol 22(1): 149-155.

Kim WS, Song SY, Ahn YC, Ko YH, Baek CH, Kim DY, Yoon SS, Lee HG, Kang WK, Lee HJ, Park CH, Park K (2001) CHOP followed by involved 
field radiation: is it optimal for localized nasal natural killer/T-cell lymphoma? Ann Oncol 12(3): 349-352.

Krone CA, Ely JT (2005) Controlling hyperglycemia as an adjunct to cancer therapy. Integr Cancer Ther 4(1): 25-31.

Lamkin DM, Spitz DR, Shahzad MM, Zimmerman B, Lenihan DJ, Degeest K, Lubaroff DM, Shinn EH, Sood AK, Lutgendorf SK (2009) Glucose as a prognostic factor in ovarian carcinoma. Cancer 115(5): 1021-1027.

Lee J, Park YH, Kim WS, Lee SS, Ryoo BY, Yang SH, Park KW, Kang JH, Park JO, Lee SH, Kim K, Jung CW, Park YS, Im YH, Kang WK, Lee MH, Ko YH, Ahn YC, Park K (2005) Extranodal nasal type NK/T-cell lymphoma: elucidating clinical prognostic factors for risk-based stratification of therapy. Eur J Cancer 41(10): 1402-1408.

Lee J, Suh C, Park YH, Ko YH, Bang SM, Lee JH, Lee DH, Huh J, Oh SY, Kwon HC, Kim HJ, Lee SI, Kim JH, Park J, Oh SJ, Kim K, Jung C, Park K, Kim WS (2006) Extranodal natural killer T-cell lymphoma, nasal-type: a prognostic model from a retrospective multicenter study. J Clin Oncol 24(4): 612-618.

Lee YY, Choi CH, Kim CJ, Song TJ, Kim MK, Kim TJ, Lee JW, Kim BG, Lee $\mathrm{JH}, \mathrm{Bae}$ DS (2010) Glucose as a prognostic factor in non-diabetic women with locally advanced cervical cancer (IIB-IVA). Gynecol Oncol 116(3): 459-463.

LeRoith D, Novosyadlyy R, Gallagher EJ, Lann D, Vijayakumar A, Yakar S (2008) Obesity and type 2 diabetes are associated with an increased risk of developing cancer and a worse prognosis; epidemiological and mechanistic evidence. Exp Clin Endocrinol Diabetes 116(Suppl 1): S4-S6.

Li W, Ma Q, Li J, Guo K, Liu H, Han L, Ma G (2011) Hyperglycemia enhances the invasive and migratory activity of pancreatic cancer cells via hydrogen peroxide. Oncol Rep 25(5): 1279-1287.

Li YX, Coucke PA, Li JY, Gu DZ, Liu XF, Zhou LQ, Mirimanoff RO, Yu ZH, Huang YR (1998) Primary non-Hodgkin's lymphoma of the nasal cavity: prognostic significance of paranasal extension and the role of radiotherapy and chemotherapy. Cancer 83(3): 449-456.

Logsdon MD, Ha CS, Kavadi VS, Cabanillas F, Hess MA, Cox JD (1997) Lymphoma of the nasal cavity and paranasal sinuses: improved outcome and altered prognostic factors with combined modality therapy. Cancer 80(3): 477-488.

Luo J, Chen YJ, Chang LJ (2012) Fasting blood glucose level and prognosis in non-small cell lung cancer (NSCLC) patients. Lung Cancer-J Iaslc 76(2): $242-247$.
Medina RA, Owen GI (2002) Glucose transporters: expression, regulation and cancer. Biol Res 35(1): 9-26.

Meyerhardt JA, Catalano PJ, Haller DG, Mayer RJ, Macdonald JS, Benson AR, Fuchs CS (2003) Impact of diabetes mellitus on outcomes in patients with colon cancer. J Clin Oncol 21(3): 433-440.

Richardson LC, Pollack LA (2005) Therapy insight: Influence of type 2 diabetes on the development, treatment and outcomes of cancer. Nat Clin Pract Oncol 2(1): 48-53.

Rodriguez J, Conde E, Gutierrez A, Arranz R, Leon A, Marin J, Bendandi M, Albo C, Caballero MD (2007) The results of consolidation with autologous stem-cell transplantation in patients with peripheral T-cell lymphoma (PTCL) in first complete remission: the Spanish Lymphoma and Autologous Transplantation Group experience. Ann Oncol 18(4): 652-657.

Sonabend RY, McKay SV, Okcu MF, Yan J, Haymond MW, Margolin JF (2009) Hyperglycemia during induction therapy is associated with poorer survival in children with acute lymphocytic leukemia. J Pediatr 155(1): 73-78.

van de Poll-Franse LV, Houterman S, Janssen-Heijnen ML, Dercksen MW, Coebergh JW, Haak HR (2007) Less aggressive treatment and worse overall survival in cancer patients with diabetes: a large population based analysis. Int J Cancer 120(9): 1986-1992.

Vose J, Armitage J, Weisenburger D (2008) International peripheral T-cell and natural killer/T-cell lymphoma study: pathology findings and clinical outcomes. J Clin Oncol 26(25): 4124-4130.

You JY, Chi KH, Yang MH, Chen CC, Ho CH, Chau WK, Hsu HC, Gau JP, Tzeng CH, Liu JH, Chen PM, Chiou TJ (2004) Radiation therapy versus chemotherapy as initial treatment for localized nasal natural killer (NK)/ T-cell lymphoma: a single institute survey in Taiwan. Ann Oncol 15(4): 618-625.

Zhou XH, Qiao Q, Zethelius B, Pyorala K, Soderberg S, Pajak A, Stehouwer CD, Heine RJ, Jousilahti P, Ruotolo G, Nilsson PM, Calori G, Tuomilehto J (2010) Diabetes, prediabetes and cancer mortality. Diabetologia 53(9): 1867-1876.

This work is published under the standard license to publish agreement. After 12 months the work will become freely available and the license terms will switch to a Creative Commons AttributionNonCommercial-Share Alike 3.0 Unported License. 